\title{
THE ECONOMICS OF PEACE AND WAR IN THE CHINESE MILITARY CLASSICS
}

\section{MATTHEW MCCAFFREY}

Matthew McCaffrey is Lecturer in Enterprise, Manchester Enterprise Centre, University of Manchester. He may be reached at matthew.mccaffrey@mbs.ac.uk.

\section{Abstract}

While some classics of Chinese military and strategic thought, like Sun Tzu's The Art of War, are well-studied by researchers and business professionals, lesser-known works in China's military canon have been neglected. This article surveys seven major ancient Chinese texts and discusses the contribution of each to the political economy of peace and war. As a rule, the writings stress the importance of nonviolent conflict resolution and advocate the avoidance of war whenever possible. In addition, they also consider the role of the state in war-making, especially its methods of war finance and attempts to encourage or discourage economic activity. They generally warn the state to limit its expenditure and impositions on the population so as to encourage the production of resources for use in military campaigns, should they become necessary.

$\mathrm{F}$ or several centuries following the decline of the Western Chou dynasty (1045-770 BC), and prior to unification in $221 \mathrm{BC}$, the territories of what today is China were divided and ruled by a number of competing states. This period in the nation's history is considered one of its most important, as political decentralization encouraged some of China's greatest cultural and economic achievements. ${ }^{1}$ Among these are listed numerous works of military strategy, most famously, Sun Tzu's The Art of War. Usually dated to the Spring and Autumn (722-481 BC) and Warring States (403-221 BC) periods, these classic military writings provide a window into the social and political upheaval that characterized the age.

Throughout the five centuries from the Western Chou to the founding of the Ch'in dynasty, the scale and scope of warfare in China increased dramatically, and with disastrous results for the populations of combatant states who found their lives and livelihoods destroyed by conflict. War was fierce and nearly constant, and often resulted in the extermination of losing states. This is evidenced by the fact that although more than one hundred kingdoms existed in the Spring and Autumn era, during the Warring States era, the major competitors were reduced to seven: the Ch'i, Yen, Han, Chao, Wei, Ch'u, and Ch'in. Each was eventually conquered by Ch'in, which completed its unification of China in $221 \mathrm{BC}$. It was in this context of incessant hostility that Chinese military thought developed: Constantly facing the threat of destruction, it became necessary for rulers across China to attract talented advisers whose wisdom would grant a competitive edge and secure the survival of the state.

Scholars of many disciplines have since looked to the Chinese military classics for insight into confrontation and conflict resolution. The most famous of these works, Sun Tzu's
Art of War, has been translated many times over, and analyzed by practically every branch of the social sciences and humanities, and especially by the business disciplines. The reason for this attention is that Art of War contains a system of strategic thought that lends itself to social science interpretations. In particular, there is an emphasis in Sun Tzu's thought on universal principles of strategy that are often cast in essentially economic terms.

However, numerous other works are included in the canon of classic Chinese strategic thought. Like Art of War, these lesser-known texts also contain commentary on the economic aspects of peace and conflict. This article surveys their insights in an effort to position Chinese military classics among other important writings on the political economy of warfare. Because Sun Tzu's Art of War is the most well-known text, and because it contains and inspires lines of thought common to other classic writings, I discuss it first. I then examine several others in turn: (1) Sun Pin's Military Methods, (2) T'ai Kung's Six Secret Teachings, (3) Methods of the Ssu-ma, (4) Wu Tzu, (5) Wei Liao-tzu, and (6) Three Strategies of Huang Shih-kung. ${ }^{2}$ Traditionally, there are seven Chinese military classics: Sun Tzu's Art of War and those just listed, excepting Sun Pin's text, plus a book known as Questions and Replies Between T'ang T'ai-tsung and Li Wei-kung which dates from the late T'ang or Northern Sung period. However, because Questions and Replies focuses on military problems and is largely a summary and discussion of ideas found in the other classics, I have replaced it with Sun Pin's work, which has a more economic tone.

Table 1 lists the name of each text, its traditional author, and its likely era of composition. Importantly, the historical origins of all of the texts are disputed as they are often 
Table 1: Texts, traditional authors, and possible dates of composition

$\begin{array}{lll}\text { Era } & \text { Text } & \text { Traditional author } \\ \text { First Period } & \begin{array}{l}\text { Ssu-ma Fa } \\ \text { Art of War }\end{array} & \begin{array}{l}\text { Ssu-ma } \\ \text { Sun Tzu }\end{array} \\ \text { Second Period } & \text { Wu-tzu } & \text { Wu Ch'i } \\ \text { Third Period } & \begin{array}{l}\text { Six Secret Teachings } \\ \text { Three Strategies }\end{array} & \begin{array}{l}\text { T'ai Kung } \\ \text { T'ai Kung }\end{array} \\ & \begin{array}{l}\text { Wei Liao-Tzu } \\ \text { Military Methods }\end{array} & \begin{array}{l}\text { Wei Liao } \\ \text { Sun }\end{array}\end{array}$

fragmented or have been heavily emended throughout the centuries. Although each work tends to be attributed to a single author, they were most likely compiled over a period of time by followers of the traditional authors (some of whom may even be fictional). Even taking account of recent archeological discoveries, the best one can hope for are broad guesses as to actual author and era. However, following the translator's suggestions, I tentatively assign the classics to three periods roughly corresponding to the beginning, middle, and end of the Warring States era. ${ }^{3}$

\section{Sun Tzu's Art of War}

Sun Tzu's classic needs relatively little introduction, as it is well-known in the West. In particular, Art of War has been studied most often in relation to business management and business ethics. However, scholars have long argued the relevance of the text for the social sciences generally, and its economic implications are still studied. For the purposes of this article, two points are worth emphasizing: the costs of war and the need to avoid armed conflict. ${ }^{4}$

Art of War emphasizes first and foremost the destructive costs of war and the need to engage in armed conflict only as a last resort. Even in extreme cases, where fighting becomes necessary, wars should be limited to the smallest and least costly scale possible. This point might not be obvious from a cursory reading of the text, however: The opening lines declare that "Warfare is the greatest affair of state, the basis of life and death, the Tao to survival or extinction. It must be thoroughly pondered and analyzed." ${ }^{\prime \prime}$ It might seem as if Sun Tzu glorifies warfare, or at the very least undervalues peace, but a closer reading reveals a fundamental concern with the destructive effects of conflict.

Sun Tzu ponders the money costs of military campaigns as well as the destruction of wealth they entail. He also indicates the tremendous costs to human welfare, both in terms of loss of life and national morale. ${ }^{6}$ The greatest costs of war appear
Sun Tzu's The Art of War is a widely-known and well-studied classic of Chinese military thought. This article introduces and discusses less well-known classic Chinese military and strategic writings and examines them in regard to the economics of peace and war. As a rule, the writings stress the importance of nonviolent conflict resolution and advocate the avoidance of war whenever possible.

whenever actual conflict occurs, and especially when it is prolonged. Thus, Sun Tzu states that "No country has ever profited from protracted warfare." ${ }^{\prime 7}$ A long campaign can only bankrupt the victorious nation while destroying the conquered. Extended warfare is essentially self-defeating; a Pyrrhic victory is no victory at all.

The text elaborates, explaining that superior strategy takes every opportunity to reduce conflict and destruction:

In general, the method for employing the military is this: Preserving the [enemy's] state capital is best, destroying their state capital second-best. Preserving their army is best, destroying their army second-best ... Subjugating the enemy's army without fighting is the true pinnacle of excellence ... Thus one who excels at employing the military subjugates other people's armies without engaging in battle, captures other people's fortified cities without attacking them, and destroys other people's states without prolonged fighting. He must fight under Heaven with the paramount aim of 'preservation.' Thus his weapons will not become dull, and the gains can be preserved. ${ }^{8}$

These passages highlight one of the fundamental themes in Art of War, namely, that the greatest achievement in war is to win without violence: "Subjugating the enemy's army without fighting is the true pinnacle of excellence." In order to do this, the superior strategist must attack the enemy's plans rather than its soldiers or fortifications. The greatest strategies should anticipate the opponent's plans to neutralize them before they can be set in motion. Conflict becomes unnecessary when victory is achieved before the enemy can act. As Sun Tzu puts it: "If I do not want to engage in combat, even though I merely draw a line on the ground and defend it, he will not be able to engage me in battle because we thwart his movements." ${ }^{, 10}$ The superior strategist makes war impossible for his enemies, and in this sense, preserves the state.

\section{Sun Pin's Military Methods}

The text attributed to the Warring States strategist Sun Pin is also entitled Art of War, although, to avoid confusion, it is also given the name Military Methods. Sun Pin is reputed to have 
been a blood descendant of Sun Tzu, and there are indeed numerous similarities in their thought. But Sun Pin's writings are not part of the traditional canon of Chinese military classics, probably because for many centuries no surviving copies were known to exist. The historical influence of his ideas has therefore been limited. However, in the early 1970s, fragments of Sun Pin's text were recovered in a Western Han-dynasty tomb in Shantung province. Reconstruction of the fragments, which unfortunately contain many irrecoverable portions of text, has revealed a work very much in the tradition of Sun Tzu. It is in turn being studied in the social sciences, for instance with regard to its economic significance. ${ }^{11}$

In matters of securing peace and avoiding warfare, Sun Pin largely follows the lead of his ancestor, stating that "One who detests warfare is the army's true kingly implement." 12 Nevertheless, as with Sun Tzu, an underlying theme of Sun Pin's thought is that war is sometimes a necessary means of survival for the state. ${ }^{13}$ Sun Pin also devotes more space than Sun Tzu to discussing relations between rulers and citizens in wartime. Especially important, he suggests that the state should not be restricted in its efforts to finance warfare:

Private and state wealth are one. Now among the people there are those who have insufficient longevity but an excess of material goods, and those who have insufficient material goods but an excess of longevity. Only enlightened kings and extraordinary men know this, and therefore can retain them. The dead will not find it odious, those from whom it is taken will not be resentful. This is the inexhaustible Tao. When properly implemented, the people will exhaust their strength. Those near the ruler will not commit thievery, those far away will not be dilatory. ${ }^{14}$

The idea is that the affluent and the dead can be relieved of their wealth without complaint or hardship. However, Sun Pin's ideas for expanding the role of the state might be broader than this passage implies. In one of the damaged portions of text, when Sun Pin is asked how to strengthen the army, he replies "enrich the state." 15 The portions of text that explain this comment are lost, but some commentators have reconstructed the probable meaning: It is likely that Sun Pin is counseling the ruler to support the state by allowing the people enough freedom to prosper and accumulate wealth, ${ }^{16}$ a policy that will both strengthen them for military service and generate the wealth necessary to finance expensive campaigns.

\section{T'ai Kung's Six Secret Teachings}

Several of the Chinese military classics have received little or no attention in Western social science, an unfortunate fact given the wealth of material they contain. One such work which does not enjoy the wide translation and application as the Sun family wisdom, is translated as Six Secret Teachings. Although it purports to be a chronicle from the late Shang and Western Chou dynasties, the conventional version of the text probably dates from the Warring States period. ${ }^{17}$ Six Secret Teachings recounts the advice of a strategist now known as the T'ai Kung to two Chou kings, Wen and $\mathrm{Wu}$, and describes the strategies that led to their overthrow of the debauched Shang dynasty. This unique historical context, whether the time line for the origin of the text is accurate or not, means it is the only Chinese military classic written from the perspective of a revolutionary endeavor. ${ }^{18}$ It also means the text devotes special attention to strengthening the state economically and organizationally in preparation for war, even while claiming that the purpose of war should be to promote social order and peace. As in many of the other military classics, war is thought of as a last resort, to be used when there is no other way to restore harmony.

One reason Six Secret Teachings likely derives from the Warring States era is its incorporation of ideas from major philosophical schools that did not exist at the time of the Shang's overthrow. In particular, tenets of Confucianism, Taoism, and Legalism all are present in the text and clearly influence its strategic and economic outlook. ${ }^{19}$ Each of these will be mentioned below.

In general, Six Secret Teachings attempts to outline ideal methods for constructing a social, economic, and military basis for the growth of the Chou state, to enable it to depose the Shang and return order to the kingdoms. The key to defeating a strong and established enemy state lies in building a prosperous and loyal state of one's own. It must be led by a benevolent ruler concerned with the people's welfare, one who will not only provide for their material wellbeing, but also demonstrate moral superiority over the enemy state. A Confucian influence is clear in this doctrine.

Wise rulers must provide benefits to the populace if they want to encourage loyalty and good service. In the words of the T'ai Kung: "In general, people hate death and take pleasure in life. They love Virtue and are inclined to profit. The ability to produce profit accords with the Tao. Where the Tao resides, All under Heaven will give their allegiance. ${ }^{20}$ It is therefore vital to extend profit to the people, and securing prosperity is both good and necessary when building a strong state. If the ruler does not share benefits with his subjects, he cannot hope to win their allegiance: “All under Heaven is not one man's domain. All under Heaven means just that, all under Heaven. Anyone who shares profit with all the people under Heaven will gain the world. Anyone who monopolizes its profits will 
lose the world." ${ }^{21}$

In terms of public policy, sharing profit generally means limiting state activity and allowing the populace to flourish without fear of interference:

When the people do not lose their fundamental occupations, you have profited them. When the farmers do not lose the agricultural seasons, you have completed them. When you reduce punishments and fines, you give them life. When you impose light taxes, you give to them. When you keep your palaces, mansions, terraces, and pavilions few, you give them pleasure. ${ }^{22}$

Therefore, a wise ruler will be frugal and will not impose onerous duties on the public, or abuse his office. The T'ai Kung goes so far as to recommend that "Rewards and punishments should be implemented as if being imposed upon yourself. Taxes should be imposed as if taking from yourself. This is the Way to love the people." ${ }^{23}$ The idea that the ruler should share in the hardships of the people is emphasized in Six Secret Teachings and leads naturally to the idea that rulers will often govern best by governing least. As an example of this type of governance, the T'ai Kung mentions one of the legendary Sage emperors who succeeded by "managing affairs through nonaction." 24

In other words, a ruler who wants to groom his state for success in warfare must adhere to a generally laissez-faire policy, although the concept of laissez-faire as such would have been unknown to the classical strategists. Nevertheless, a relatively free populace can produce the material basis for government: "The ruler must focus on developing wealth within his state. Without material wealth he has nothing with which to be benevolent." 25 There is some similarity between the T'ai Kung's view and Sun Pin's ideas about enriching the state. This makes sense as both texts likely date from the same period. Both have precedents in Chinese philosophy as well, especially in Taoism, some branches of which contain definite anti-state ideas. ${ }^{26}$ However, the strategists have different ends in mind: The military authors wish to use prosperity as a potential source of war finance and as a tool for encouraging loyalty to the state, goals the Taoists did not share.

Six Secret Teachings also offers advice on how to promote trade in a way that works to the state's advantage. The T'ai Kung instructs King Wen to safeguard the ruler's "three treasures," which are "great agriculture, great industry, and great commerce. ${ }^{\prime 27}$ Each of the treasures refers to a different type of economic activity: agriculture to farming, industry to the artisans, and commerce to the merchant class. The emphasis on trade might appear to be an endorsement of the division of labor and commercial society. However, in the T'ai Kung's opinion, because each of these roles is vital, individuals should not be allowed to move between classes, lest they become distracted and abandon their "natural" duties. ${ }^{28}$ Even though the T'ai Kung advocates a certain degree of economic freedom, then, he believes there should be limitations on the self-determination of the people. In addition to regulating the major professions, ministers should not be wealthier than rulers, and no city should be larger than the capital. ${ }^{29}$ Again, it is important to remember that the advice in Six Secret Teachings is designed to produce a victorious war machine, which in the T'ai Kung's view requires restrictions on production and the division of labor.

\section{Three Strategies of Huang Shih-kung}

Traditionally, Three Strategies of Huang Shih-kung is also attributed to the T'ai Kung. Allegedly, it collects his strategic thought from a period toward the end of his life, following the Chou defeat of the Shang, the preparation for which inspired Six Secret Teachings. The two texts can therefore be thought of as bookends to the T'ai Kung's career, with Three Strategies focusing on peacetime administration following the conflict. As usual, the validity of the traditional authorship and dating is highly doubtful. Nevertheless, it is still useful as a way of framing the discussion.

Three Strategies has a more pronounced Taoist influence than some of the other classics, although it bears the heavy imprint of Confucian and Legalist thought as well. It emphasizes the importance of peace while leaving room for Confucian-style wars of rectification. In terms of economic policy, Three Strategies extensively develops the idea of a state in harmony with itself and the world, from the ruler down to the lowest-ranked common people. Conventional strictures about rewards and punishments as incentives are included throughout, along with extended discussions of the importance of employing worthy men while punishing the corrupt who sow confusion and discord and threaten the stability of the state.

Also prevalent is the notion that material welfare is the basis for a strong state and can only be cultivated if government restricts its predation:

To treat the people as they should be treated means concentrating on agriculture and sericulture and not disturbing the people during their vital seasonal occupations. It means keeping taxes and impositions to a minimum, not exhausting their wealth. If you impose few labor services, if you do not cause the people to be overly labored, then the state will be prosperous and the families 
will enjoy pleasure. Only thereafter should you select officers to control and supervise them. ${ }^{30}$

Laws and regulations were viewed by the Taoists as artificial creations embodying a decline from virtue, ${ }^{31}$ and this passage reflects the Taoist belief in limited governmental and bureaucratic interference in the lives of the people.

\section{The Methods of the Ssu-ma}

The text entitled Ssu-ma Fa, translated as The Methods of the Ssu-ma, was compiled in the fourth century BC, and coincides with the flourishing of military thought associated with strategists such as Sun Tzu and Sun Pin. In antiquity, the term Ssu-ma was a title that came to mean Minister of War, and the text appears to gather the insights of numerous men who held this position. Its original ideas pertain mostly to military administration and therefore give glimpses into the economic outlook of the authors, although fewer than some of the other texts. Ssu-ma Fa is the shortest of the military classics, having lost many of its chapters over time.

In accord with the Confucian doctrines of the period, the text discusses the importance of a righteous ruler who cultivates his Virtue, in turn leading to peace and harmony within the state. This is a common theme throughout the military classics, as mentioned below in the discussions of $W u$ $T z u$ and Wei Liao-tzu. However, in some ways the Ssu-ma Fa is more bellicose than other military writings, arguing that war is the true basis of political authority and is required to maintain the state. The need to govern thus implies the need for war, and governance is used as a justification for campaigns of rectification. According to The Methods, while campaigns are destructive, they are the means to an end: "If one must attack a state out of love for their people, then attacking it is permissible." ${ }^{32}$

Like Six Secret Teachings, The Methods recommends that rulers as much as possible avoid imposing burdens of warfare on the people, especially through disturbing agricultural production or by imposing corvée labor. This principle applies both to one's own populace and to that of the enemy: Foreign peoples must be protected during military campaigns and their persons and property be left undisturbed. ${ }^{33}$ This policy seems to reflect, in part, humanitarian thinking in the Confucian vein, but also indicates the more Legalist notion that people must be made comfortable so that they will submit to new rule. Furthermore, numerous passages mention the need to ensure the loyalty of the people so that they can be effectively used by the state (an idea further discussed in the next section). The $\mathrm{Ssu}-\mathrm{ma} \mathrm{Fa}$ is therefore less useful as a guide to achieving peace than are some of the other military classics that stress the disadvantages of war and the importance of winning without fighting.

\section{Wu Tzu}

Wu Ch'i (c. 440-361 BC), whose life bridged the late Spring and Autumn and early Warring States periods, is considered to have been one of China's first great generals, a reputation reflected by the frequent juxtaposition of his name with Sun Tzu's. ${ }^{34}$ His stature as a strategist receives further testimony through the preservation of $W u T z u$, a text attributed to him and that allegedly recounts his life and teachings. Like the other military classics, $W u T z u$ is a hybrid of sorts, combining elements of Confucian and Legalist teachings and focusing heavily on the importance of law and the power of the state. It is therefore similar to the Ssu-ma Fa in that it is less interested in encouraging peace as such than in effectively executing war. Just like the other classic authors, Wu Ch'i emphasizes the use of rewards and punishments as fundamental tools for managing the army. ${ }^{35}$ However, for him basic incentives are not by themselves sufficient to mold an obedient and effective fighting force. ${ }^{36}$ In the Warring States period, Sawyer comments,

[t]he mass mobilization of farmers to serve as combat infantrymen rather than simply as support troops meant their volitional consent had to be sought as well as coerced. They could easily flee to other states, most of which were beginning to welcome people to bring new lands under cultivation and increase the state's agricultural wealth. ${ }^{37}$

This reality meant that in order to ensure a steady supply of soldiers and domestic resources for war finance, states had to incorporate subtler methods of persuasion, especially those of the moral sort. This can be done, according to Wu Ch'i, by training the people to pursue the Confucian notion of righteousness, especially through observing the forms of propriety - the $l i$ - which can help encourage a sense of shame in those who ignore the needs of the state. ${ }^{38}$ The desire to pursue righteousness and avoid shame can therefore be employed as more fundamental incentives than can simple material rewards and punishments.

The ideal of Confucian righteousness can also be used as a tool for promoting the interests of the state (a more Legalist notion), specifically, its desire to wage war. Military campaigns can be righteous from a Confucian perspective-if, for example, war is intended to restore harmony by deposing a debauched ruler - and using Confucian ideas to convince the people of the importance of the cause helps subvert natural desires to avoid conflict. War was clearly not in the interest of 
the population that would be drafted into the army as well as obliged to finance the conflict. Like the Ssu-ma Fa, then, $W u$ $T z u$ is not very helpful as a guide to peaceful relations.

\section{Wei Liao-tzu}

Wei Liao is yet another author about whom little is known other than that he appears to have lived in the late 4th century BC. His book, Wei Liao-tzu, is similar to the other military classics in that it involves a discussion between the ostensible author and a ruler asking for advice in military matters. In this case, though, Wei Liao is called on to suggest policies that will halt the decay and eventual conquest of a state and return it to greatness.

Military and economic concerns come together naturally for Wei Liao, who suggests that economic conflict is the root of military conflict. ${ }^{39}$ Increasing the power of the state therefore requires carefully managing and exploiting the resources of the people; hence, it also means encouraging economic activity of a sort. In one of the few explicit references to the power of markets found in the military classics, Wei Liao notes that weak states must rely on economic activity as a source of war materiel:

Now if [one's resources] are neither sufficient to go forth to wage battle nor adequate to remain within the borders and defend the state, one must correct [the insufficiency] with markets. Markets are the means to provide for both offensive and defensive warfare. If a state of ten thousand chariots lacks states of one thousand chariots to assist it, it must have markets able to furnish one hundred chariots ...

Looking without seeing and listening without hearing stem from the state not having markets. Now markets are offices for sundry goods. [The government should] buy items which are cheap in the market and sell those that have grown expensive in order to restrain the aristocrats and the people ... [W]hy is it the people have a famished look and the horses an emaciated appearance? The markets have goods to deliver, but the office lacks a controller. Now if you raise the best-trained army under Heaven but do not manage the sundry goods, this is not what is referred to as 'being able to conduct warfare. ${ }^{40}$

Relatively developed markets are therefore necessary to provide resources to the state. ${ }^{41}$ Yet Wei Liao is quick to add that these markets must be controlled by the state as well. Furthermore, the state is an active participant, as seen in the policy of buying cheap and selling dear. This, Wei Liao believes, will allow the state to take full advantage of the productive activity of the people. ${ }^{42}$
To strengthen the state, Wei Liao recommends increasing the population and maximizing agricultural production: "When the land is broad and under cultivation, the state will be wealthy; when the people are numerous and well-ordered, the state will be governed." ${ }^{33}$ Once again one sees the notion, common to the classics, that material wealth and wellbeing must be fostered by the state - and impositions limited - so as to provide the material foundation for warfare, establish the state's own benevolence, and encourage loyalty. ${ }^{44}$ Productivity might also serve as a basis for peace, because when a state is strong, it need not wage war: "When the state is wealthy and well-governed, although the people do not ... expose their armor, their awesomeness instills order on All under Heaven." ${ }^{45}$

Wei Liao also advises that armies should avoid destroying the lives and livelihoods of the people of opposing nations. ${ }^{46}$ While Wei Liao does not frown on economic activity per se, he intends it to be regulated and controlled so that the interests of the populace and the state do not drift apart. Although stressing the importance of Confucian virtue in both government and the people, the Legalist theme of a strong authoritarian regime dominates his discussion, which advocates strict ideological and behavioral conformity with the state. ${ }^{47}$ For the state to maintain control over its subjects, the people must be rigidly directed to those duties deemed necessary to its survival and strength: "We should cause that, apart from engaging in agriculture, there will be no means to eat, and apart from engaging in battle, there will be no means to attain rank. We should cause the people to bump into each other in competing to go out to the farms and into battle. Then under Heaven we will have no enemies!" ${ }^{48}$ Prosperity is intended to strengthen the state and make it attractive to potential immigrants as well. The growing power of the state therefore discourages potential enemies from making war, seemingly promoting a kind of peace; but under an essentially Legalist form of rule, it is the peace of totalitarianism.

\section{Conclusion}

Although the classical strategists discuss war more often than peace, they do not take conflict lightly. In fact, economic elements in their thought often lead them to emphasize avoiding conflict whenever possible. For them, the ultimate victory is to win without fighting, and they eschew frequent, lengthy, and wasteful campaigns. The classics should not be read as endorsements of war, but rather as descriptions of how to execute it as quickly and painlessly as possible when it does become necessary. Unfortunately, the advice of the sages was seldom if ever put into practice historically, as the Spring and Autumn and Warring States eras witnessed a persistent 
increase in the frequency and violence of war. Simply put, the power to define the necessity of war-making lay in the hands of states. It was possible, and common - especially through the Confucian notion of rectifying the wicked-for states to rationalize warfare based on nebulous conceptions of necessity, often involving the correction of an injustice. For all that they caution against war then, the military classics were unable to prevent it.

One important conclusion from all this is that problems of peace and warfare ultimately revolve around the state, an idea shared by contemporary social science researchers. In economics, for instance, the state is sometimes defined as an institution with a comparative advantage in violence, ${ }^{49}$ and economists of several schools contend that states are inherently prone to war. ${ }^{50}$ In fact, Charles Tilly (a sociologist) argues that warfare explains the emergence and persistence of the modern nation-state: Because only a relatively prosperous state can afford to bear the (historically increasing) cost of war, economic resources must be organized in such a way that they can be effectively exploited by government. ${ }^{51}$ These ideas should not come as a surprise, given Sun Tzu's dictum that war is fundamentally about the state's survival, or the comments of other strategists regarding the need for the state to nurture economic activity for its own use. The Chinese military classics hint that the problems of ending warfare and promoting peace have their explanations in the nature of the state, and they certainly view warfare as a defining characteristic of government. Their ideas dovetail with contemporary research on the economics and sociology of violence, and even anticipate it to some extent.

In addition to their strategic insights, it is also worth studying the military classics as early artifacts of economic thought. Although economics as a distinct discipline did not emerge for many centuries after China's Warring States period, it was at roughly this time that ancient thought around the world began to develop different conceptual frameworks for economic thinking. To take one example, in their efforts to explain the nature of the polis, Greek thinkers also emphasized the military arts and agricultural production as fundamental institutions. ${ }^{52}$ And similar lines of thought, especially stressing agriculture as the economic basis of society, appear to have been common throughout the ancient world. Old Testament, New Testament, early Christian, and Arabic writings sometimes criticize wealth accumulation through commerce, favoring instead relatively static agricultural societies. Several Roman authors argued along the same lines, including Cicero, whose ideas regarding the honorable profession of agriculture influenced some sixteenth-century cultures. ${ }^{53}$

One especially interesting avenue for future research is the relation between classical strategic thought and the institutional environment in which it flourished. For instance, how did Chinese political institutions influence the development of strategic thought? Did states reward innovation in military strategy at the expense of productive market entrepreneurship, à la William Baumol, and if so, does this help to explain the agricultural and sometimes anti-commercial attitude of the classics? Answers can only come from further research. But whether we find answers or not, it should be clear that the Chinese military classics provide ample opportunities for further discussion, especially in the economics and sociology of conflict, the history of strategy and warfare, and the history of political and economic thought.

Notes

1. Long (2003).

2. An anonymous referee points out that we cannot assume that a modern reading of these texts is consistent with what the historical authors meant. I agree and emphasize that this article is interpretive more than it is strictly historical. My aim is to add to the modern interpretations of the classics found in both Chinese and English-language literatures. Throughout, I rely on the work of Ralph D. Sawyer who has translated the military classics and provided extensive commentary (Sawyer, 1995; 2007). The Romanization and any bracketed material in the quotations that follow are his. Note that I use the names of the traditional authors to refer generically to the numerous individuals who (likely) authored and compiled the texts over time.

3. Sawyer (1995, pp. 73-77; 2007, pp. 16-18). For further discussion of competing theories regarding these historical details, cf. Sawyer (2007).

4. Social sciences: Boorman and Boorman (1964). Economics: See McCaffrey (2014).

5. Sawyer, Art of War (2007, p. 157). Note that when a reference is to a translated text, the text is indicated (here: Art of War). When no text is indicated, the reference is to Sawyer's commentary.

6. Sawyer, Art of War (2007, pp. 159-160).

7. Sawyer, Art of War (2007, p. 159).

8. Sawyer, Art of War (2007, pp. 160-161; emphasis added).

9. Sawyer, Art of War (2007, p. 161).

10. Sawyer, Art of War (2007, p. 167).

11. McCaffrey (2015).

12. Sawyer, Military Methods (1995, p. 101).

13. Sawyer, Military Methods (1995, p. 84).

14. Sawyer, Military Methods (1995, p. 127). A fuller interpretation of the economic content of this passage is found in McCaffrey (2015).

15. Sawyer, Military Methods (1995, p. 156). 
16. Sawyer (1995, pp. 159-160).

17. Sawyer (2007, pp. 35-37).

18. Sawyer (2007, p. 27).

19. The basic tenets of Confucianism and Taoism are well known. Legalist philosophy focused especially on expanding the power of the state. Although not a formal school of thought, the Legalists generally opposed commerce and favored a strictly regimented agricultural society dominated by a strong state. Rulers are responsible for economic planning, which they enforce through a system of harsh punishments used as incentives (Fu, 1993, pp. 38-46).

20. Sawyer, Six Secret Teachings (2007, p. 42).

21. Sawyer, Six Secret Teachings (2007, p. 41; emphasis in original).

22. Sawyer, Six Secret Teachings (2007, p. 43). This passage is followed by another outlining the negative effects of the opposite policies (pp. 43-44).

23. Sawyer, Six Secret Teachings (2007, p. 44).

24. Sawyer, Six Secret Teachings (2007, p. 42). Nonaction evokes the Taoist notion of limited government interference with the populace. The Sage emperor's behavior is also described in more detail, for example: "What he allotted to himself was extremely meager, the taxes and services he required of the people extremely few. Thus the myriad peoples were prosperous and happy and did not have the appearance of suffering from hunger and cold" (p. 43).

25. Sawyer, Six Secret Teachings (2007, p. 47).

26. Carreiro (2013).

27. Sawyer, Six Secret Teachings (2007, p. 46).

28. One commentary adds that immobility between employments makes sense on Legalist grounds as well because it would make citizens easier to monitor and control (Sawyer, 2007, p. 402, n. 11).

29. Sawyer, Six Secret Teachings (2007, p. 46).

30. Sawyer, Three Strategies (2007, p. 294).

31. Long (2003).

32. Sawyer, The Methods of the Ssu-ma (2007, p. 126).

33. Sawyer, The Methods of the Ssu-ma (2007, pp. 126-128).

34. Goodrich (1981-1983).

35. Sawyer, Wu Tzu (2007, p. 214); McCaffrey (2014).

36. Sawyer (2007, p. 204).

37. Sawyer (2007, p. 457, n. 29).

38. Sawyer, Wu Tzu (2007, p. 208).

39. Sawyer (2007, p. 461, n. 12).

40. Sawyer, Wei Liao-tzu (2007, pp. 255-256).

41. Sawyer (2007, p. 473, n. 116).
42. This is an example of market entrepreneurship falling prey to unproductive or political entrepreneurship, as discussed in Baumol (1990) and McCaffrey and Salerno (2011).

43. Sawyer, Wei Liao-tzu (2007, p. 243).

44. Sawyer, Wei Liao-tzu (2007, pp. 254-255, 259); Sawyer, (2007, pp. 232-233).

45. Sawyer, Wei Liao-tzu (2007, p. 243).

46. Sawyer, Wei Liao-tzu (2007, p. 273).

47. Sawyer (2007, pp. 233-234).

48. Sawyer, Wei Liao-tzu (2007, p. 246).

49. North (1981, p. 21).

50. Salerno (2008).

51. Tilly (1990).

52. Rothbard (2006, pp. 7-8).

53. Baloglou (2012).

References

Baloglou, C.P. 2012. "The Tradition of Economic Thought in the Mediterranean World from the Ancient Classical Times Through the Hellenistic Times Until the Byzantine Times and Arab-Islamic World," pp. 7-91 in J. Backhaus, ed. Handbook of the History of Economic Thought. New York: Springer. http://dx.doi.org/10.1007/978-1-4419-8336-7_2

Baumol, W.J. 1990. "Entrepreneurship: Productive, Unproductive, and Destructive." Journal of Political Economy. Vol. 98, No. 5, pp. 893-919. http://dx.doi.org/10.1086/261712

Boorman, S.A. and H.L. Boorman. 1964. "Mao Tse-tung and the Art of War." Journal of Asian Studies. Vol. 24, No. 1, pp. 129-137. http://dx.doi.org/10.2307/2050423

Carreiro, D.R. 2013. "The Tao Against the Tyrant: The Limitation of Power in the Political Thought of Ancient China." Libertarian Papers. Vol. 5, No. 1, pp. 111-152.

Fu, Z. 1993. Autocratic Tradition and Chinese Politics. Cambridge, UK: Cambridge University Press.

Goodrich, C.S. 1981-1983. “Ssu-ma Ch'ien's Biography of Wu Ch'i.” Monumenta Serica. Vol. 35, pp. 197-233.

Long, R. 2003. "Austro-Libertarian Themes in Early Confucianism." Journal of Libertarian Studies. Vol. 17, No. 3, pp. 35-62.

McCaffrey, M. 2014. "The Political Economy of the Art of War." Comparative Strategy. Vol. 33, No. 4, pp. 354-371. http://dx.doi.org/10.1080/01495933.2014.941725

McCaffrey, M. 2015. “The Economics of Sun Pin's Military Strategy." http://papers.ssrn.com/sol3/papers.cfm?abstract id=2539656 [accessed 18 December 2014].

McC̄affrey, M. and J.T. Salerno. 2011. "A Theory of Political Entrepreneurship.” Modern Economy. Vol. 2, No. 4, pp. 552-560. http://dx.doi.org/10.4236/me.2011.24061

North, D.C. 1981. Structure and Change in Economic History.

The Economics of Peace and Security Journal — ISSN 1749-852X — http://www.epsjournal.org.uk (C) EPS Publishing, 2015. All rights reserved. For permissions, email: ManagingEditor@epsjournal.org.uk 
New York: Norton.

Rothbard, M.N. 2006. Economic Thought Before Adam Smith. Auburn, AL: The Ludwig von Mises Institute.

Salerno, J.T. 2008. "Imperialism and the Logic of War Making." Independent Review. Vol. 12, No. 3, pp. 447-457.

Sawyer, R.D. 2007. The Seven Military Classics of Ancient China. Translation and commentary by R.D. Sawyer, with Mei-Chün Sawyer. New York: Basic Books. ["T'ai Kung's Six Secret Teachings," pp. 40-105; "The Methods of the Ssu-ma," pp. 126-143; "Sun Tzu's Art of War," pp. 157-186; “Wu Tzu," pp. 206-224; "Wei Liao-tzu," pp. 242-276; "Three Strategies of Huang Shih-kung," pp. 292-306.]

Sawyer, R.D. 1995. Sun Pin: Military Methods. Boulder, CO: Westview Press. [“Military Methods," pp. 79-244.]

Tilly, C. 1990. Coercion, Capital, and European States, AD 990-1990. Oxford, UK: Basil Blackwell. 